\title{
16 MART 1921 MOSKOVA ANDLAŞMASI'NA TÜRK VE RUS KAYNAKLARINA GÖRE KARŞILAŞTIRMALI BIR BAKIŞ
}

\author{
Yrd. Doç. Dr. Vefa KURBAN \\ Dokuz Eylül Üniversitesi, Edebiyat Fakültesi, \\ Tarih Bölümü
}

\begin{abstract}
ÖZ
Ekim devriminden sonra Rusya I.Dünya Savaşı'ndan Brest Litovsk Andlaşması'nı imzalayarak çekilmiştir. Savaştan mă̆lup çıkan ülkelerden bir diğeri de Osmanlı Türkiye'si idi. Rusya'da gerçekleşen iç savaş, Polonya Savaşı, Sovyetlerin komünizmi doğuya yayma politikalarl ve dünya emperyalizminin temsilcisi olan Ingiltere ile karşılaştıkları sorunlar, Sovyetleri Ankara Hükümeti ile yakınlaştırmıştır. Ankara Hükümetinin de bu dönemde Sovyetlere ihtiyacı vardır. Çünkü Türkiye'de Mustafa Kemal Paşa önderliğinde "Misak-ı Milli" çerçevesinde bağımsız milli bir devlet kurmak isteyen hükümet söz konusudur.

Çalışmada, Rusya'nın o dönemdeki siyasi ve ekonomik durumu da ele alınarak değerlendirilmiştir.

Çalışmada, ayrıca bu iki ülke arasında 16 Mart 1921 tarihinde imzalanan Moskova Andlaşması'nı doğuran sebepler ve bu dönemdeki siyasi durum, karşılaştırmalı olarak, hem Sovyet tarihçilerinin, hem de Türk tarihçilerinin yorumları ile ele alınmıştır. Andlaşmanın iki ülke arasında yeni bir dönemi başlatmış olduğu da vurgulanmiştır.
\end{abstract}

Anahtar Kelimeler: Pakistan Sovyet, Moskova Andlaşması (1921), TBMM, Mustafa Kemal Paşa, V.İ.Lenin

\section{ACCORDİNG TO THE TURKISH AND RUSSİAN SOURCES A COMPARATIVE OVERVIEW ON THE MOSCOW TREATY OF MARCH 16TH 1921}

\begin{abstract}
After the October Revolution, Russia withdrew from the World War I signing the Treaty of Brest-Litovsk. On the other side, the Ottoman Empire was also defeated in the War. Additionally, the civil war taking place in Russia, the Poland War, and Soviet policies aiming to spread Communism to the east, and the problems between Soviet Russia and Britain, the representative of world imperialism, helped the development of friendly relations between the Soviet Russia and Ankara Government. In that period, the Government of Ankara needed the support of the Soviets, because the Government aspired to found an independent State within the "Misak- Milli" (National Oath/ national borders) of Turkey under the leadership of Mustafa Kemal Pasha.

The present analyzes the political and economical status of Russia during that period.
\end{abstract}


Furthermore, the present study addresses the underlying reasons of the Moscow Treaty, which was signed between Russia and the new Government on March 16, 1921 and the political status in Russia during that period by comparing the interpretations of Turkish and Russian historians. It is also emphasized in the study that the aforementioned treaty started a new era between the two countries.

Keywords: Soviet, Treaty of Moscow (1921), Grand National Assembly of Turkey, Mustafa Kemal, V.İ.Lenin

\section{Brest-Litovsk Andlaşması Sonrasında Türk-Sovyet İlişkileri}

Ekim Devriminden sonraki ilk aylarda Türkiye, Almanya tarafinda Rusya'ya karşı savaşıyordu. Almanya ile birlikte Osmanlı Devleti de BrestLitovsk Andlaşması'nın imzalayıcılarından birisiydi. (Potemkin, 1945:39-40). Sovyet Rusya, 1. Dünya Savaşı'ndan Almanya ve müttefikleriyle, Kirillov'a göre “kendisi için utanç verici” bir andlaşma olan Brest Litovsk Andlaşması'nı imzalayarak çıkmıştır. Bu andlaşmayla Rusya, Polonya, Baltık ülkeleri, Ukrayna, Beyaz Rusya'nın bir bölümü ve Kafkasya'daki toprakların bir bölümünü kaybediyor, 3 milyar ruble de tazminat ödemek durumunda bırakılıyordu. Aynı zamanda Rusya'nın, Merkezi ve Doğu Avrupa'da devrim propagandas1 yapmas1 yasaklanıyordu. (Kirillov, 2012: 425).

Osmanlı Devleti'ni Brest-Litovsk görüşmelerinde, Berlin sefiri İbrahim Hakkı Paşa ve Ateşemiliter Zeki Paşa temsil ediyorlardı. 16 Aralık 1917'de Zeki Paşa, Brest-Litovsk'da Sovyet heyetinden L.B. Kamenev ile görüşmüştür. Enver Paşa'nın talimatıyla Rus işgali altındaki toprakların boşaltılması teklifinde bulunmuş ve Rus işgal bölgesinde Ermenilerin Müslüman halka yaptıkları mezalimden bahsederek, bunun bir an önce durdurulmasını istemiştir (Bal, 2004:25).

Gromıko'nun ifadesine göre, Türkiye yönetimi Brest-Litovsk Andlaşması'nı bozarak, Kafkasya'ya askeri müdahale başlattı. Fakat Türkiye, tecrübesizliğinin sonucunda Dörtlü İttifak'ın diğer mağlup güçleriyle aynı kaderi paylaştı. 30 Ekim 1918 tarihinde İtilaf Devletleri, Türkiye'yi Mondros Ateşkes Andlaşması'nı imzalamaya zorladı. (Gromıko,1980:108). Bu andlaşmaya göre, Çanakkale ve İstanbul Boğazı, galip devletler tarafından ele geçirildi ve kendi savaş gemileri için boğazlar açık kaldı, ordu terhis edildi, İstanbul, telgraf sistemi ve bütün demir yolları kontrol altına alındı. (Soysal, 2000: 12-14).

Mondros Ateşkes Andlaşması, Türkiye'nin fiilen bölünmesinin başlangıcı oldu. Paris Barış Konferansı'nda ABD Başkanı Wilson, Türk topraklarına yönelik bir dizi ilkeler ileri sürdü (ACE,1978:480). Böylece Türkiye, ulusal bağımsızlığını tamamen kaybetmek tehlikesiyle karşı karşıya kald1. (Gromıko, 1980:109).

\section{Komünizmin Propagandası}

Rusya'da Komünizmin yaşayabilmesi için diğer kapitalist memleketler de komünist olmalı idiler. Sovyet Hükümeti’nin 1917 sonrası dış politikası ihtilal propagandacılığından oluşmaktadır. Bu propaganda faaliyeti için Mart 
1919'da Komintern teşkilatı kuruldu. Komintern'in faaliyet amaçları aşağıdaki şekilde idi:

- Komünist fikirlerini yaymak için milletlerarası propaganda yapmak,

- Başka memleketlerdeki komünist partilerini desteklemek ve onlara yardımda bulunmak,

- Dünya komünist ihtilalini hazırlamak. (Esmer, 1953: 29-30).

Ekim devrimini yapanlar, Rusya’dan sonra dünya komünist ihtilalini de gerçekleştirmek istiyordu. Komünist ihtilalinin gerçekleşmesi için doğuya bakılmaya başlandı. Osmanlı Devleti'nin yenilmesine rağmen doğuda önemi çok büyüktü. Doğuda destek aranırken Anadolu'daki gelişmeleri değerlendirmemek mümkün değildi. (Bilge, 1992: 60).

Lenin ve bütün Bolşevikler, Rus ihtilalinin, dünya ihtilalinin başlangıcı olacağı düşüncesindeydiler. "Ruslar başladı, Almanlar, Fransızlar, İngilizler takip edecek ve sosyalizm başarıya ulaşacaktır... Alman ihtilali gerçekleşmezse biz mahvoluruz" ifadeleri Lenin'in ağzından düşmüyordu. (Gürün, 1991: 13).

$\mathrm{Bu}$ dönemde Sovyetler Birliği'nin Türkiye'ye yaklaşımı, dünya devrimine destek arama yolunda geçici bir anlaşma ve dünya emperyalizmini temsil eden İngiltere'yi yıkmak için zorunlu bir yardımdır. (Bilge, 1992: 61).

Sovyet dönemi tarihçileri ise olayı farklı biçimde yorumlamaktadırlar: “Osmanlı Devleti'nin savaştaki yenilgisi ve Ekim Devrimi'nin etkisiyle, Mustafa Kemal Paşa'nın önderliğinde, İtilaf Devletlerinin emperyalizmine ve iç isyanlara karşı kurtuluş mücadelesi başladı. Bu zor mücadelelerinde Türk halkınin yardımina Sovyet Rusya koştu." (Dokument1, 1959:683).

13 Eylül 1919 yılında Rusya Federasyonu Dişişleri Halk Komiseri, Türkiye'nin işçi ve köylülerine hitaben: "Türk işçi ve köylüleri! Sizin Rus işçi ve köylü kardeşleriniz, içten kan emenlerin ve Rusya'yı dıştan parçalayan yırtıcıların, Avrupalı soyguncuların iplerini ele almaya karar verdiler. Ve böylece, neredeyse iki yıldır onlar, kendilerini ve iş̧̧ileri güçlendirmek için mücadele ediyorlar. Artık Sovyet Rusya'sının emek ve işçi üzerindeki düşmanı yenip zafer kazanmasına çok az kaldl. Fakat bu da yeterli değil, zalimlere karşı bütün Dünya işçilerinin dayanışma içerisinde olması gerekiyor.

Bu önemli zamanda Rusya iş̧̧isi ve köylüsü, siz Türk işçi ve köylü kardeşlerinin yardım elini bekliyor ve ortak düşmanımı olan, bizim acılarımızdan mutluluk duyan yırtıcı Avrupa soyguncularını üzerimizden defetmeğe çağırıyor." (İzvestiya, 1919).

\section{Türk-Sovyet Yakınlaşmasının Sebepleri ve Ermenistan Faktörü}

Sovyetler Birliği'nin Türkiye'ye yaklaşmasına fiili bir zorunluluk da eklenmiştir. $\mathrm{Bu}$ da Sovyetler Birliği'nin Polonya yenilgisidir. Bu yenilgi, Bolşeviklerin dış politikasında bir dönüm noktasıdır. Bu durum, Sovyetler Birliği'nin Ermenistan'da Türkiye'ye karşı bir hareket geliştiremeyeceğini de ortaya koyuyordu. Dolayli olarak Ermeni isteklerini desteklemeye devam edemeyeceğini gösteriyordu. (Bilge, 1992:61). 
Nisan 1920'de Atatürk'ün önderliği ile Türkiye'de hükümet kuruldu ve merkez Ankara oldu. Türkiye'deki bu devrim, İtilaf devletlerinin, özellikle de İngiltere'nin şiddetli tepkisine neden oldu. Artık 26 Nisan'da Kemal Paşa hükümet adına diplomatik ilişkilerin kurulması teklifi ile Türk halkına işgal kuvvetleriyle adil mücadelesinde olası yardımın gösterilmesi ricasını içeren bir mektupla Sovyet Rusya'sı Hükümetine başvurmuştur. (Gromıko,1980:108110).

Felsefe bakımından Türkiye'nin Sovyetler Birliği'ne yaklaşımı da çok farklı değildi. Türkiye, milli sınırlar içerisinde bağımsız devlet kurmak istiyordu. Milli mücadelenin başarıya ulaşması için dış yardıma ihtiyaç vardı. BMM'nin 22 Ocak 1921 tarihli gizli toplantısında, Atatürk bu fikrini açıklamıştır. (Bilge, 1992:61).

3 Haziran 1920'de Sovyet Dış İşleri Halk Komiserliği, Sovyet Hükümetinin, Yeni Türk Devletinin temel iç prensiplerini memnuniyetle karşıladığını Kemal Paşa'ya bildirmiştir. (Dokument1,1959:555).

Sovyet Hükümeti bir an önce Türk Hükümeti ile diplomatik ve konsolosluk ilişkilerin kurulması ve görüşmelere başlanması konusundaki rızasını bildirdi ve Sovyetlerin, Ermenistan-İran-Türkiye arasındaki sınır tespiti konusunda arabulucu rolünü üstlenmeyi de kabul ettiğini vurguladı. (Dokument1,1959:555).

Sovyet Dişişleri Halk Komiseri Georgiy Çiçerin'in 3 Haziran 1920 tarihli mektubunda şöyle yazıyordu: "Sovyet Hükümeti olarak, Türk halkının kendi bağımsızlık ve egemenliği uğruna verdiği kahramanca mücadeleyi ilgiyle izlemekten ve Türkiye için bu zor günlerde Türk ve Rus halkını birleştirecek dostluğun sağlam temelini atmaktan mutluluk duyuyoruz." (Dokument1,1959:555).

4 Temmuz 1920’de Türk Hükümeti Dışişleri Bakanı Bekir Sami Bey cevabi mektubunda, Sovyet Hükümeti'nin yanıtının Türkiye Hükümeti tarafından büyük coşkuyla karşılandığını ve Sovyet Hükümeti'nin Ermenistanİran-Türkiye arasında arabuluculuk yapma önerisine olumlu tepkisini açıklamıştı. Bekir Sami Bey aynı zamanda Türkiye Büyük Millet Meclisi’nin bu savaşta Türkiye Hükümeti'nin Sovyet Hükümeti ile beraber yürüttükleri mücadele sonucunda kapitalistlerin ve emperyalistlerin üstesinden geleceklerine inandığını da vurgulamıştır. (Dokumentı, 1959:556).

"Yüksek Meclis’in izlediği politika hiçbir vakitte komünist esasına dayalı değildir... Milli esaslara derin bağlarla sadık kalan Meclisiniz ve Hükümetiniz bağımsız bir devlet olarak Rusya Bolşevik Cumhuriyeti denilen bir devletle siyasi ilişkilerinde hiçbir vakit Komünistlik ile Bolşeviklik esasların ăgzına almamıştır..." (Zabıt:333).

Bekir Sami Bey Moskova'ya vardıktan sonra, Kafkasya’nın durumunda önemli değişiklikler olmuştur.

27-28 Nisan 1920'de Azerbaycan'da Bolşevik rejim iktidara gelmiş, Mayıs-Haziran 1920'de Erivan Ermeni Cumhuriyetinde Bolşevik ayaklanmaları 
olmuştur. Gürcüler, 7 Mayıs'ta Sovyet Azerbaycan'1 ile, 6 Haziran 1920'de ise Sovyet Rusya ile andlaşmalar imzalamışlardır. Sovyet Rusya, Gürcistan'ın bağımsızlığını tanımıştır. (Gönlübol, Sar, 1997:17).

2 Temmuz 1920'de Mustafa Kemal'e, Türkiye Hükümeti ve Sovyet Rusya'sı arasındaki karşılıklı ilişkileri içeren bir mektup iletildi. Buna istinaden Bekir Sami Bey’in başkanlığı altında bir Türk heyeti Moskova’ya gitti. Orada Türk-Rus andlaşmasının taslağı hazırlandı. (Dokumentı,1959:556).

Bekir Sami Bey heyeti ile Sovyet Hükümeti arasında 24 Ağustos 1920 'de bir anlaşma tasarısı parafe edildi. Fakat Sovyet Dışişleri Halk Komiseri Çiçerin'in, Kafkasya'da Türkiye'ye ait bazı bölgelerin Ermenistan'a verilmesini istemesi üzerine, andlaşmanın imzalanması mümkün olmamıştır. (Gönlübol, Sar,1996:25). Görüşmeler sırasında Çiçerin: "Türklere yardım, Ermenistan hudutlarının tahdidi meselesi ve Türkiye'nin kendi toprakları dahilinde bulunan diğer milletlerin hukuklarına riayet edilmesi, diye söze girmiş, eski Ermeni vilayetlerinden(!) Bitlis, Van ve Muş...” diye bahsedince, Türk murahhas heyeti reisi: "Türkiye'de hiçbir zaman bir Ermeni vilayeti bulunmamıştır" diye cevap vermiştir. (Cebesoy, 2002:68-69).

Şüphesiz ki, Mustafa Kemal de Bolşeviklerin asıl amacının ne olduğunu bilmekte ve Sovyetlerle münasebetlerini buna göre ayarlamaktaydı. (Gönlübol, Sar,1996:17).

Bekir Sami Bey, taslağ yanına alarak Türkiye'ye dönmüştür.

$\mathrm{Bu}$ arada İstanbul ${ }^{1}$ hala padişahlık dönemini yaşamaya devam ediyordu ve İngiliz-Fransız askerlerinin işgali altındaydı. 20 Ağustos 1920'de İtilaf Devletleriyle yapılan Sevr Andlaşması sonucunda Türkiye, topraklarının büyük bir kısmından mahrum kaldı. (Erim,1953:525-545). BMM Hükümeti bu andlaşmayı sert bir şekilde kınadı.

$\mathrm{Bu}$ dönemde Rusya'nın ekonomik durumunun hiç de iyi olmadı̆̆ anlaşılmaktadır. 1920 yılı ve 1921 yılının başlarında "askeri komünizm" politikası ülke ekonomisini çöküşün eşiğine getirmiştir. Hem dört yıl süren Birinci Dünya Savaşı, hem de üç yıl süren iç savaş sonucunda Rusya'nın nüfusu 10,9 milyona düşmüştür. İşyerleri faaliyetlerini durdurduğundan işçiler, şehirleri terk edip köylere yerleşiyorlardı, Bu dönemde Petrograd iş̧̧ilerinin $\%$ 60. Moskova işçilerinin ise \%50 kadar azaldığı tespit edilmiştir. 30 demiryolunun ulaşımı durdurulmuştur. Enflasyon artmıştır. 1921 yılında şehirlerde ve köylerde açlık yaşanmaktaydı. (Orlov,2013:353).

Sovyet dönemi tarihçilerinden A.A.Gromıko bu dönemdeki Türkiye ile İtilaf devletleri arasındaki ilişkileri aşağıdaki şekilde değerlendirmiştir:

“Ingiltere ve Fransa, Türkiye Hükümeti'nin Sovyet Hükümeti'yle işbirliği yapmasina sıcak bakmıyordu... Bu durum Türk Hükümeti'ne Kafkasya'da toprak fethi meselesini düşündürdü. Kemalist Hükümet,

\footnotetext{
${ }^{1}$ Sovyet tarihçileri İstanbul'dan bahsederken 1950'li yıllarda bile "Konstantinopolis" ismini kullanmayı tercih etmişlerdir.
} 
Ermenistan ile müzakerelerde Sovyet Hükümeti'nin arabuluculuğunu reddetti. Ermeni Taşnak Hükümeti'ne karşı bir savaş başlatıldı”. (Gromıko, 1980:108).

Öte yandan Doğu sinırlarındaki 15. Kolordu Kumandanı Kazım Karabekir Paşa, Ermenilerin Türklere ve Müslümanlara yaptıkları zulüm ve cinayetleri duydukça Ermenistan'a karşı harekete geçmek için 1srarla ve üst üste TBMM’nin iznini istiyordu. Ruslarla birlikte Ermenistan’a bir hareket tertip etme ümidi olmadığı anlaşılınca Ankara hükümeti kendi imkânlarıyla ve Rusya'ya haber vermeden 28 Eylül'de Ermenistan'a hareketi başlatmak zorunda kalmıştır. (Bilge, 1992:62-63).

2 Aralık 1920 yılında Türkiye galip sıfatıyla Ermenistan'la Gümrü Andlaşmasını imzaladı ise de 29 Kasım 1920'de Erivan’da Sovyet Ermenistan Hükümeti kurulmuştu. (Soysal, 2000: 17-23).

Türkiye emperyalistlere karşı savaşmaktan zayıf düşmüştü. Onun bu durumunu gören Yunan birlikleri de saldırıya geçmişti. $\mathrm{Bu}$ şartlar altında Türkiye Hükümeti’nin Sovyet Hükümeti’nden yardım alması hayli önemliydi. Şubat 1921'de TBMM Milletvekili Yusuf Kemal Bey'in başkanlığında bir Türk heyeti tekrar Moskova’ya gitti. (Benhür, 2008:277-313). Görüşmelerde Türkiye Hükümeti, Sovyet Hükümeti ile ilişkilerin daha da geliştirilmesini ve İngiliz emperyalizmine karşı yardım isteğini bildirmiştir.

Moskova' da bu görüşmeler yapılırken, aynı zaman dilimine denk gelen günlerde Bekir Sami Bey'in başkanlığı altında bir heyet de Londra'da İtilaf Devletlerin de bulunduğu konferanstaydı. İngiltere Başbakanı Lloyd George, Bekir Sami Bey'e Bakü petrol sahaları dahil olmak üzere bütün Kafkasya'nın Türkiye himayesi altına geçmesine hazır olduğunu bildirdi. İngiltere Başbakanı bu önerinin Türkiye-Sovyet ilişkilerinin bozulmasına sebep olabileceğini ve Ermenistan, Gürcistan, Azerbaycan'1 teşvik ederek Sovyet yardımlarından mahrum kalabileceğini de hatırlattı. Bu gizli görüşmeyle ilgili bilgiler dışarıya da sızmıştı. G.V. Çiçerin bu provokatif İngiliz girişimine Türk heyetinin dikkatini çekmişti:

"Haklı olarak bu soruyu sormam gerekiyor, Bekir Sami Bey kimi temsilen buradadır, Konstantinopolis'i mi (Osmanlı), yoksa Ankara'yı mı (Hükümet)? Bu son durumla ilgili hangi yönde ne gibi değişiklik var, ĕger herhangi bir değişiklik varsa, Türkiye'nin bizi bu karardan daha önce haberdar etmesi gerekiyor..." (Dokument1, 1959:589-590).

Gromıko, “Ankara'dan gelen talimat üzerine, gelen Türk heyetinin, Ingilizlerin önerilerini sadece klşkırtıcı bir provokasyon olduğunu vurguladı̆̆ını ve Kemalist Hükümetin Sovyet Hükümeti ile olan andlaşmayı imzalamak arzusunda olduğunu tüm samimiyetiyle dile getirdiğini" yazmaktadır. (Gromiko, 1980:109).

26 Şubat 1921 tarihinde Moskova'da yapılan Rus-Türk genel kurul toplantısında Sovyet tarafinın Yönetim Kurulu Başkanı G. V. Çiçerin, konuşma sırasında Sovyet Hükümeti ile Doğu ülkeleri arasındaki dostça ilişkilerin değerini vurgulamıştı: "Doğu halklarıla dostluk ilişkileri kurmak bizim 
uluslararası yaşamımızda ana fikirdir ve Türkiye'nin siyasi konumu bunun temelidir. Bizim kurtuluşumuz ve siyasi gücümüz için ettiğimiz bu mücadelede Doğu ülkeleri ile olan ittifakımı devam edecektir. Bu dostluğun halklarımızı birleştirerek resmi ve nihai andlaşmaya yansıması gerekiyor." (Mejdunarodnaya,1958:156).

Türk heyetinin başkanı Yusuf Kemal Bey Türkiye ve Rusya'nın ortak çıkarlarının olduğunu kabul ederek aralarındaki bu işbirliğinin önemli olduğu yanıtını vermiştir:

"Türk halkının Rus işçisine, köylüsüne ve askerine açı yüreklilikle yardım elini uzatacağını temin ediyorum. Coğrafi, tarihi, ekonomik ve politik koşullar bize Rusya yolunu gösterdi. Rusya Hükümeti karşısında Türk halkı adına bütün samimiyetimle bize inanin diyorum." (Mejdunarodnaya,1958:156).

$\mathrm{Bu}$ arada, Afganistan'ın Moskova'ya gönderdiği bir delegasyon ile, Türk-Sovyet Andlaşmasını görüşmekte olan Türk delegasyonu arasında da 1 Mart 1921 tarihinde Türkiye-Afganistan Andlaşması imzalanmıştır. (Soysal, 2000: 24).

\section{16 Mart 1921 Moskova Andlaşması}

Müzakereler sonucunda 16 Mart 1921 tarihinde Moskova'da, TürkiyeSovyet Rusya Dostluk ve Kardeşlik Andlaşması imzalanmıştır.

Yusuf Kemal Tengirşek'in hatıralarında yer alan bu andlaşmayla ilgili şu bilgilere de değinmek gereklidir:

"1921 yilınin Mart ayının 18. günü, Türk-Sovyet Rusya muahedesi, merasim-i mahsusa ile imza edildi. Bir sene evvel tam bu tarihte, Çamlica tepelerinin liman tarafindaki kiyılarını teşkil eden Şemsipaşa'da, yıkık bir duvarın üstünde, şehre ateş edecekmiş gibi İstanbul'a doğru çevrilmiş olan düşman donanmasının toplarına bakarak benliğime, kanıma verdiğim söz yerine gelmeye başlamıșt. Bu sebepledir ki, İngilizlerle yaptıkları ticaret muahedesinden dolayı Rusların da işine geldiği için, muahedenin altına 18 Mart değil, İstanbul'un işgalinin ylldönümü günü olan 16 Mart tarihini koyduk. Osmanlı İmparatorluğu'nun tarihte iki büyük düşmanından biri samimi olarak bize dost olduğunu, bu defa öbür düşmanla tarihte birkaç defa olduğu gibi birleşerek Türk topraklarını paylaşmaya kalkışmayacağını taahhüt ediyordu.", (Tengirşek,1981:218).

Muahedeye TBMM hükümeti adına Yusuf Kemal, Riza Nur, Ali Fuat, Sovyetler Birliği adına da Hariciye Komiseri Çiçerin ile Celal Korkmazof imza atmıştır. (Cebesoy,2002:153).

Emperyalizme karşı mücadele eden bu iki ülke ilişkilerinde önemli bir yeri olan dostluk ve kardeşlik andlaşmasının birinci maddesine göre; Sovyet Hükümeti, Büyük Millet Meclisi'ni ve Meclisin seçtiği hükümeti Türkiye'nin yasal hükümeti olarak tanıdığını beyan etmiş ve Misak-1 Milli (Soysal, 2002:1516) sınırlarını Türkiye sınırları olarak tanımıştır. (Dokumentı,1959:599). Böylece ilk defa büyük bir devlet Misak-1 Milli'yi tanımış oluyordu. (Oran,2001:573). 
Ardahan ve Kars Türkiye’de kalarak kuzey-doğu sınırı belirlenmiştir. İkinci maddeye göre Batum, Gürcistan'a geri verilecek ancak Türkiye Batum limanını serbestçe kullanabilecekti. Nahçivan, özerk bir statüde bırakılmış ve kontrolü Azerbaycan'a verilmiştir. Türkiye Doğu Cephesindeki kuvvetlerini Batıya kaydırmak olanağına kavuşmuştur. Türkiye, Sovyet Hükümeti'nin İtilaf Devletlerine karşı politik desteğini ve Türkiye'ye yardım göndermesini sağlamıştı. Halk serbest bir şekilde istediği bölgeye göç etme hakkını elde etmiş ve halka özgürlük hakkı tanınmıştı. Sovyet Hükümeti, iki ülke arasında yapılmış olan tüm eski andlaşmaları iptal etmiş, Türkiye'nin Çarlık Hükümeti'ne olan bütün mali yükümlülüklerini ortadan kaldırmıştı. (Potyemkin,1979:236-237).

$\mathrm{Bu}$ arada kapitülasyonlar da kaldırılmıştı. Karadeniz kıyı rejimi ve boğazlar meselesi daha sonra toplanacak bir konferansta kararlaştırılacaktı. Bu konferansa Karadeniz'e kıyıs1 olan diğer devletlerin de katılmas1 öngörülmüştür. Her iki ülke diğerinde faaliyet gösteren zararlı örgütleri desteklemeyeceğini belirtmekte ve Kafkas halklarının üzerinde ortak yükümlülükler üstlenmektedir. (Dokument1,1959:599).

Sovyet Hükümeti, İngilizlerin ve Yunanların Türkiye’ye yapmış olduğu vahşeti de kınamıştı. Sovyet-Türk Andlaşması bağımsızlık mücadelesinde Ankara'nın pozisyonunu da kuvvetlendirmiştir. Diğer devletlerle yapılacak olan görüşmelerde de Ankara'nın aynı şekilde başarılı andlaşmalar imzalamasına zemin hazırlamıştır. (Gromıko, 1980:110).

On beşinci maddeye göre Sovyetler Birliği, Türkiye ile Kafkasya ülkeleri olan Azerbaycan-Ermenistan-Gürcistan Sovyet Sosyalist Cumhuriyetleri arasında imzalanan andlaşmalarda aktif bir şekilde görev almıştır. Çünkü Moskova Andlaşması yapıldığı sırada Ermenistan, Azerbaycan ve Gürcistan'da Sovyet Cumhuriyetleri kurulmuş ve onların Moskova'ya bağları kesinleşmişti. Fakat bu Cumhuriyetlerin o sırada Lenin'in milliyetler ilkesinin canlılı̆g nedeniyle, sınırları da kapsayan bir konuda onun benzeri olan yeni bir andlaşmayı ayrıca imzalamaları öngörüldüğü içindir ki, 15. Madde ile bu yolda bir hüküm konulmuştur.

Türkiye ile Ukrayna Sovyet Sosyalist Cumhuriyeti arasında 2 Ocak 1922 tarihinde Ankara'da bir Dostluk ve Kardeşlik Andlaşması da imzalanmıştır. (Soysal, 2000:31).

13 Ekim 1921 tarihinde Kars’ta, Rusya Sovyet Federatif Sosyalist Cumhuriyeti'nin de katılımılla Türkiye ile Azerbaycan-Ermenistan-Gürcistan Sovyet Sosyalist Cumhuriyetleri arasında andlaşma imzalanmıştır. (Soysal, 2000: 39-47). Bu andlaşma, 16 Ekim 1921 tarihinde imzalanan Moskova Andlaşması'nın bir tamamlayıcısı niteliğindeydi.

Rusya ve Türkiye arasındaki Moskova Andlaşması'nda bazı notlar dikkat çekmektedir. 16 Mart 1921 tarihli notlardan birinde:

"Rusya ve Türkiye arasındaki dostluk ilişkilerinde, emperyalizme karşı birlikte mücadelede onlartn birbirine güvenmesi önemlidir. Gelecekte 
Türkiye'nin diğer devletlerle yapacă̆ her türlü müzakerelerin ayrıntısını Rusya'ya bildirmesi gerekir" deniliyordu. (Dokument1,1959:606).

Aynı tarihli Sovyet Dış İşleri Halk Komiseri'nin yazdığı notta, Sovyet Hükümeti'nin Türkiye'nin yükümlülüğünü üstleneceğine dair Türkiye'ye taahhüt verilmekteydi. (Dokument1,1959:606-607).

16 Mart 1921 tarihli başka bir notta Türkiye, TBMM adına bir taahhütte bulundu:

"Türkiye dış politikası yönünde her hangi bir değişiklik olması durumunda bunu Rusya'ya bildirecek ve Rusya ile birlikte karar verecekti”. Rusya Dış İşleri Halk Komiseri, bu nota Sovyet Hükümeti adına olumlu tepki verdi. (Gromiko,1980:112).

16 Mart 1921 tarihinde Rusya ile Türkiye arasında imzalanan Moskova Andlaşması'nda, Türkiye'ye 10 milyon altın ruble tutarında mali yardım sağlanması da kararlaştırılmıştı. Bu miktarın 5,4 milyon altın rublesi 1921 yılı Nisan, Mayıs ve Haziran aylarında dilimler halinde Türkiye'ye teslim edilmiştir. ${ }^{2}$

Rusya için de zor bir dönemdi, ülkenin ekonomik durumu henüz düzelmemişti. Buna rağmen Sovyet Hükümeti, 1921 yılının sonlarında Türkiye'ye yine 1,1 milyon altın ruble teslim etmiştir. (Dokument1,1959:675). Bu para, İngiltere tarafından desteklenen Yunanistan'la savaşan Türk ordusuna, silah ve savaş malzemesi almak için gerekiyordu. (Gromıko,1980:113).

Vurgulanması gereken bir diğer husus da; Londra' da İtilaf devletleri ve Türkiye arasında yapılmakta olan görüşmeler başarısızlıkla sonuçlanmıştı. TBMM Hükümeti, yeni Türkiye'nin kabul edemeyeceği, gerici padişah hükümetinin imzaladığı Sevr Andlaşması'ndan vazgeçilmesini istiyordu. Ama o sıralarda, itilaf devletleri doğal olarak bu isteği kabule yatkın değillerdi. (Aralov, 1985:25).

\footnotetext{
${ }^{2}$ Sovyet belgelerine göre yapılan yardımlar: 1920 yazında 6000 tüfek, 5 milyon kadar tüfek mermisi, 17600 top mermisi, 1920 Eylül'ünde $200.6 \mathrm{~kg}$ külçe altın, 1921 Ocak-Şubat aylarında 1000 atımlık top barutu, 4000 el bombası, 4000 şarapnel mermisi. 1921 yılında yapılan yardım: 33275 tüfek, 57986000 tüfek mermisi, 327 makineli tüfek, 54 top, 129479 top mermisi, 1500 kılıç, 20000 gaz maskesi.

3 Ekim 1921'de Jivoy ve Jutkiy adı iki destroyer Trabzon'da Ankara hükümetine devredilmiştir.

16 Mart 1921 Andlaşmasından sonra 10 milyon altın rublelik akçalı yardım andlaşması yapılmış ve bu akçalı yardım şu şekilde verilmiştir: Nisan 1921'de 4 milyon, MayısHaziran 1921'de 1.4 milyon, Kasım 1921'de 1.1 milyon, Mayıs 1922'de 3.5 milyon. Kaynak: Fahir Armaoğlu, 20.yüzyıl Siyasi Tarihi, cilt 1-2 (1914-1995), Ankara, 2010, s. 313-314.
} 
Sovyet Hükümeti'nin Türkiye'ye yaptığı yardım, sadece mali yardımla sınırlı değildi. A.A.Gromıko, Mihail Vasilyeviç Frunze'nin ${ }^{3}$ Türkiye'yi ziyaretini şu şekilde açıklamaktadır:

“M. V. Frunze'nin Türkiye'yi ziyaretinin önemli bir sebebi vardl. Ukrayna Sovyet Cumhuriyeti adina gerçekleşen bu ziyarette amaç, Türkiye ile Ukrayna Sovyet Cumhuriyeti arasındaki ilişkileri geliştirmekti. Frunze'nin ziyareti Türk-Yunan savaşı zamanına denk gelmişti. Bu yüzden Frunze'nin ziyaret amacı Türkiye-Ukrayna ilişkilerini geliştirmenin daha da ötesine geçti. Kasım 1921'de Frunze Türkiye'ye geldi. Yolculuk yorucu geçmişti. M. V. Frunze ve onun heyeti Ankara'ya yolun büyük bir kısmını faytonlarla gitmek zorunda kalmıştı. (Gromıko, 1980:108).

20 Aralık 1921'de Frunze, TBMM ile toplantıda Sovyet HükümetiTürkiye dostluğunu baltalamak isteyen Batı'nın emperyalist güçlerini kınayarak: 'Şüphesiz, Batı'nın emperyalist güçleri Türkiye ile Sovyet Hükümeti arasindaki dostluğu bozmak için her türlü oyun oynayacaklar. Hatta Türkiye’ye bağımsızlık teklifleri yaparak silah zoruyla yapamadıklarını dostluk maskesi altında yapmaya çalışacaklar" demekteydi. (Gromıko,1980:114).

M. V. Frunze'nin Türkiye'yi ziyareti Mustafa Kemal tarafindan da takdir edilmiştir. ${ }^{4}$ Mustafa Kemal, Merkez İcra Komitesi Başkanı M. İ. Kalinin ve Merkez Yürütme Kurulu Başkanı G.İ. Petrovskiy’e telgraf çekmiştir:

"Kızll Ordu'nun kahraman komutanı ve önemli politikacı olan Sayın M. V. Frunze'nin Türkiye'ye ziyaretiyle, Türkiye ile Ukrayna Cumhuriyeti arasinda dostluk ilişkilerinin kurulması, tam da düssmanın bütün dünyaya bizi yeneceğini açıklamayı düşündüğ̈̈ Sakarya Savaşı dönemine denk geldi. Millet Meclisi adına derin minnettarlı̆̆ımı sunarım”. (Dokument1,1959:782).

Böylece, 29 Aralık 1921 ile 29 Nisan 1922 tarihleri arasında, Sovyet Hükümeti tarafından Novorossiysk'den Türkiye'ye tüfek, makineli tüfek, top ve top mermisi sevk edilmiştir. 1922 yılında da Türkiye'de fişek (barut) fabrikaları kurulması için gerekli teçhizat ve hammadde sağlanmıştır. 3 Mayıs 1922'de ise Sovyet Hükümeti 3,5 milyon rubleyi Türkiye Hükümetine teslim etmiştir. Bunun yanı sıra M. V. Frunze, anne-babasını savaşta kaybeden, kimsesiz çocuklar için bir yetimhane kurulması talimatı vermiştir. Bakü işçileri,

\footnotetext{
${ }^{3}$ Mihail Vasilyeviç Frunze (1885-1925). 1904 yılından itibaren Sovyet Komünist Parti üyesi, 1918 yılından itibaren Rus ordusunda hizmet etmiştir. 1909-10 yıllarında iki defa ölüm cezasına çarptırılmıştır. Sürgüne gönderilmiştir. Ekim devrimi sırasında Doğu cephesi Güney birliklerinin, Doğu Türkistan Güney cephelerinin komutanı olmuştur. 1921-1922 yıllarında Türkiye'de Ukrayna ile Türkiye arasında dostluk andlaşması imzalayan heyetin başkanlığını yapmıştır. Öldüğünde Kızıl Meydan'da defnedilmiştir. Kaynak: ACE Azerbaycan Sovyet Ansiklopedi, cilt X, Bakü1987, s. 5.

4 Mihail Frunze'nin İstanbul'da, Taksim Meydanı'nda bulunan Taksim Anıtı'nda Kliment Voroşilov ile birlikte heykeli mevcuttur. Bununla ilgili Mevlüt Çelebi'nin Dünden Bugüne Taksim Cumhuriyet Anıtı kitabına bakılabilir. Ankara, 2006.
} 
Türkiye'nin en çok ihtiyaç duyduğu bir zamanda Türkiye'ye petrol göndermişlerdir. (Gromıko, 1980:114).

2 Ocak 1922 tarihinde Ankara'da, Türkiye ile Ukrayna Sovyet Cumhuriyeti arasında andlaşma imzalandı. Bu andlaşma, 1921 yılında Türkiye ile Sovyet Hükümeti arasındaki andlaşmanın temel şartlarının tekrarı niteliğindeydi. RSFSR (Rusya Sovyet Federal Sosyalist Cumhuriyeti) temsilcisi S.İ. Aralov, ${ }^{5}$ bu konuda şöyle demiştir:

“Duyarl bir kişiliğe sahip olan Sayın Frunze'nin Türkiye'ye ziyareti, bu topraklarda derin izler bırakmıştır. O, Türkiye'nin Rusya hakkındaki yanlış anlamalarını aydınlatarak Türklerin Rusya'ya bakışını değiş̧tirmiş̧tir. Sadece Ukrayna temsilcisi değil, kararları, görüşleri ve konuşmalarıyla o aynı zamanda bütün Rusya Federasyonu'nun temsilcisidir". (Dokument1,1959:782783).

Mustafa Kemal, Türkiye ile Rusya arasındaki dostluğa büyük önem vermiştir. 18 Aralık 1920 tarihinde V. İ. Lenin'e göndermiş olduğu telgrafta Mustafa Kemal, iki ülke arasındaki dostluk bağlarının daha da güçlenmesini dilemiş, Sovyetlerin uzak görüşlü siyasetini büyük takdirle karşıladığını ifade etmiştir. (Sbornik, 1947: 69).

Kemal Paşa'nın liderliği yıllarında, Türkiye-Rusya dostluğu daha da güçlenmiş̧ir. 1921 yılında imzalanan dostluk ve kardeşlik andlaşması iki ülkenin birbirine olan güveninin temeli olmuştur.

Ermeni kökenli Sovyet tarihçilerinden E.Sarkisyan, Ankara Hükümeti ile yeni kurulan Sovyet Hükümeti arasındaki ilişkileri 1957 yılında şu şekilde değerlendirmiştir:

"Milli-burjuva anti-emperyalist devrimin, Türkiye'de anti-demokratik Kemalist rejimle sonuçlanmasina rağmen, bu devrim önemli gelişmelere sebebiyet vermiştir. Emperyalistlerin Yakındoğu ve Ortadoğu'da kendi sömürgecilik emellerini yerine getirmelerine izin vermemiştir...

Türkiye'de "milli burjuva devriminin" zaferle sonuçlanmasında Sovyet Rusya'nın maddi ve manevi desteği büyük önem taşımaktadır. Büyük Ekim Sosyalist Devrimi ve Sovyet hâkimiyetinin kurulması sayesinde, emperyalist cephe bölünmüstür ve Ingiltere, Fransa ve Amerika Birleşik Devletleri'nin Türkiye üzerindeki planlarına darbe indirmişstir.

Rusya'daki Ekim Devriminin zaferi olmasaydl, Türkiye galipler arasında paylaşılacaktı ve bir devlet olarak varlığın yitirecekti. Bu, İtilaf Devletleri ve Sultan Türkiye'si arasinda imzalanan Sevr Andlaşması ile öngörülmüştü. (Sarkisyan,1957:7-22).

\footnotetext{
${ }^{5}$ S.İ. Aralov'un eserleri: Lenin Vel Nas K Pobede (Lenin bizi zafere taşıdı), Moskova 1989

Vospominaniya Sovetskogo Diplpmata 1922-1923 (Bir Sovyet Diplomatın anıları,19221923), Moskova 1960.

Na Ukraine 40 let nazad (1919) (Ukrayna'da 40 yıl önce) Elyazısı.
} 
15 Mart 1961 yılında andlaşmanın 40. yıldönümü büyük önem taşımıştır. Bu sebeple SSCB (Sovyet Sosyalist Cumhuriyetleri Birliği) Yüksek Sovyet Başkanlığı, SSCB Bakanlar Konseyi Başkanlığı, Türkiye Cumhurbaşkanı'na çektiği telgrafta:

"Emperyalist güçlere karşı mücadele yıllarında ülkelerimiz adına V.I.Lenin ve K.Atatürk tarafindan imzalanan bu tarihi andlaşma Kurtuluş Savaşında Türk halkının zaferine katkıda bulunmuş, Sovyetler Birliği ve Türkiye Cumhuriyeti arasındaki dostluk ilişkilerinin kurulmasina sebep olmuştur" demiştir. (Pravda,1961).

\section{SONUÇ}

Sovyet tarihçilerinin 1920'lerdeki Türk-Sovyet ilişkilerini değerlendirirken vurgulamadıkları önemli bir gerçek Sovyetlerin Türkiye'ye olan ihtiyac1 meselesidir. Sovyetler, dünya emperyalizmini temsil eden İngiltere'yi yıkmak için, ayrıca komünizmin yayılması noktasında Doğuda büyük bir güç olma durumunu, savaştaki yenilgisine rağmen hala koruyan Türkiye'ye ihtiyaç duymaktaydı.

Sovyet tarihçileri Türkiye'deki gelişmeleri değerlendirirken, galibiyetin sadece Sovyetlerden gelen yardımlarla gerçekleştiğini, hatta Rusya'daki devrim gerçekleşmeseydi, Bağımsız Türk Devletinin var olamayacağını vurgulamaktadirlar.

Oysa bu dönemde Sovyetler Birliği'nin de Türkiye'ye ihtiyacı vardır. Moskova ve Kars Andlaşmalarıla, Türk-Sovyet ilişkilerinde yeni bir dönem açılmıştır. Fakat bu iki ülke arasındaki ilişkilerin, samimiyet ve güven üzerine kurulduğunu söylemeye de imkân yoktur. (Gürün, 1991: 71).

Sovyetler Birliği ile Türkiye arasında doğan güvensizlik 1921 yılının Eylül ve Ekim aylarında artmıştır. Türkiye'nin Moskova Büyükelçiliği'nin Çiçerin'e gönderdiği notalarda, yardımın aksaması, İngiltere ile anlaşma ve hatta Yunanistan ile ilişki kurma girişimleri, Büyük Millet Meclisi Hükümeti'ne muhalif olanları (yani Enver Paşa'yı) destekleme konuları ortaya konularak açıklama istenmiştir.

Çiçerin ise verdiği yanıtta, İngiltere ile anlaşmanın Türkiye'ye yardıma engel olamayacağını, Yunanistan ile esir değiş-tokuşu için olsa bile ilişki kurulmasından vazgeçildiğini, Rus hükümeti memurları, 1921 Anlaşmasına aykırı hareket etmişler ise cezalandırılacaklarını ve Büyük Millet Meclisi'ne karşı olan siyaset adamlarına yardım yapılmadığını belirtmiştir. Notada ayrıca Fransa ile Türk Hükümeti'nin yaptığı gizli anlaşmalar hakkında bilgi istenmiştir. $\mathrm{Bu}$ yazışmalar, iki tarafın 1921 Dostluk ve Kardeşlik Andlaşması'nda öngörülen danışma ve birbirleri aleyhine anlaşma yapmama yükümlülüklerine uyulmadığı iddialarını ortaya koymuştur. (Bilge,1992: 79-80)

Sonuçta, Mustafa Kemal Paşa ile Vladimir İliç Lenin arasında Milli Mücadele döneminden kalan iyi ilişkiler 1920'li y1llarda iki ülkenin birbirinden uzaklaşmasını engellemiştir. Bu durum üçüncü ülkelere karşı uluslararası 
platformlarda iki ülkenin birbirini desteklemesine sebep olmuştur. Ticari ve kültürel alanda ise ilişkilerin aynı oranda gelişmediği görülmüştür.

Her şeye rağmen, Mustafa Kemal Atatürk'ün gözünde 1921 Moskova Andlaşması, Sovyetler Birliği Hükümeti ile Büyük Millet Meclisi Hükümeti arasında var olan samimi ilişkileri resmen belirten bir belgedir. Andlaşmanın onaylanması vesilesi ile Atatürk 10 Nisan 1922'de Lenin'e gönderdiği telgrafta:

“...Rus dostluğu geçmişte olduğu gibi her zaman Türkiye Büyük Millet Meclisi Hükümeti'nin temel politikası olacaktır. Halen emperyalist ve kapitalist devletlerin ortaya attıkları yeni metotlar karşısında memleketlerimizin her zamankinden daha sıkı bir blok teşkil etme zorunluluğunda olduklarına inanıyorum. Rusya'nın birçok defalar bize yaptığı yardım, bizce özel bir önem taşımaktadır..." demiştir (Bilge, 1992: 77).

Moskova Andlaşması'nın devamında, 13 Ekim 1921'de imzalanan Kars Andlaşması'yla Moskova'nın ve Türkiye'nin önündeki önemli sorunların halledildiği görülmüştür. Türkiye'nin Doğu sınırı kesinleşmiş ve Ermeni sorunu da sona ermiştir.

Lozan'da da Rusya'nın İngiltere'ye karşı Türkiye'nin yanında veya tarafsız kaldığı görülmüştür.

İki ülke arasında II. Dünya Savaşı'na kadar cereyan eden siyasal gelişmeler, 1921 yılında imzalanan Moskova ve 1925 yılında imzalanan TürkSovyet Dostluk ve Tarafsızlık Andlaşmaları çerçevesine oturtulmuştur.

\section{KAYNAKLAR}

İvestiya Gazetesi (1919), 13 Eylül.

Mejdunarodnaya Jizn Dergisi (1958), Moskova, No:2.

Pravda Gazetesi (1961), 18 Mart.

ACE (1978) Azerbaycan Sovyet Ansiklopedisi, cilt 2, Bakü,.

ACE (1987) Azerbaycan Sovyet Ansiklopedi, cilt 10, Bakü.

ARALOV S.İ. (1989) Lenin Vel Nas K Pobede (Lenin bizi zafere taşıdi), Moskova.

ARALOV S.İ. (1919), Na Ukraine 40 let nazad (Ukrayna'da 40 y1l önce) El yazısı.

ARALOV S.İ. (1960), Vospominaniya Sovetskogo Diplomata 19221923. Moskova.

ARALOV, S.İ. (1985), Bir Sovyet Diplomatının Türkiye Anıları, çev. Hasan Ali Ediz, Ankara,

ARMAOĞLU, Fahir (2010), 20.yüzyll Siyasi Tarihi, cilt 1-2 (19141995), Ankara.

AYTEPE, Oğuz (2004), “Ankara'nın Merkez ve Başkent Olması", Ankara Üniversitesi Türk İnkılap Tarihi Enstitüsü "Atatürk Yolu” Dergisi, Say1 33-34, Mayıs-Kasım.

BAL, Halil (2004), “Brest-Litovsk Andlaşması'ndan sonra Türkiye ve Ermeniler”, "Yakın Dönem Türkiye Araşttrmaları”, say1 5. 
BASKIN, Oran (2001), Türk Dış Politikası, Kurtuluş Savaşından Bugüne Olgular, Belgeler, Yorumlar, cilt 1 (1919-1980), İstanbul.

BENHÜR, Çağatay (2008), "1920'li Yıllarda Türk-Sovyet İlişkileri, Kronlojik Bir Çalışma”, "Türkiyat Araştırmaları" Dergisi, sayı 24, Güz, 277313.

BİLGE, A.Suat (1992), Güç Komşuluk, Türkiye-Sovyetler Birliği İlişkileri, (1920-1964) Türkiye İşbankası Yayınları, Ankara.

BUTAKOV, A.N. (2012), Bresskiy Mir, Lovuşka Lenina dlya Kayzerovskoy Germanii, Moskova.

CEBESOY, Ali Fuat (2002), Moskova Hatıraları, Milli Mücadele ve Bolşevik Rusya, Temel Yayınevi, İstanbul.

ÇELEBİ, Mevlüt (2006), Dünden Bugüne Taksim Cumhuriyet Anttl, Ankara.

Dokument1 Vneşney Politiki SSSR, (1959), Moskova, cilt 3.

ERİM, Nihat (1953), Devletlerarası Hukuku ve Siyasi Tarih Metinleri, Cilt 1, Osmanlı İmparatorluğu Andlaşmaları, TTK, Ankara.

ESMER, Ahmet Şükrü (1953), Siyasi Tarih (1919-1939), Güney Matbaac1lik ve Gazetecilik T.A.O., Ankara.

GÖNLÜBOL, Mehmet-SAR, Cem (1997), Atatürk ve Türkiye'nin Dlş Politikası (1919-1938), Ankara.

GÖNLÜBOL, Mehmet-SAR, Cem (1996), Olaylarla Türk Dış Politikası (1919-1995), Siyasal Kitabevi, Ankara.

GROMIKO, A. A. (1980), Ístoriya Vneşney Politiki SSSR 1917-1980 gg, cilt 1, 1917-1945, Moskova.

GÜRÜN, Kamuran (1991), Türk-Sovyet İlişkileri (1920-1953), TTK, Ankara.

IVANOV, İ.S. (2002), Oçerki istorii Ministerstva inostrannıh del Rossii (1802-2002), Moskova, cilt 2.

KIRILLOV, V.V. (2012), Istoriya Rossii, Moskova.

ORLOV, A.S., Geogiyev B.A., Georgiyeva N.G., Sivohina T.A. (2013), Istoriya Rossii, Moskova.

POTEMKIN, V.P. (1945), İstoriya Diplomatii, cilt 2, Diplomatiya v novoe vremya (1872-1919), Moskova.

POTYEMKİN, Vladimir (1979), Uluslararası Ilisskiler Tarihi, Diplomasi Tarihi, (çev. Attila Tokat1), May yayınları, cilt 3. İstanbul.

SARKISYAN, E. (1957), "Vliyanie Oktyabrskoy Revolutsii na natsionalno-osvoboditelnoe dvijenie v Turtsii (1918-1922)" “izvestiya Akademii Nauk Armyanskoy SSR", No 10.

SONYEL, Salahi R. (1986), Türk Kurtuluş Savaşı ve Dış Politika, Cilt 2, TTK, Ankara.

Sovetsko-Turetskie Otnoşeniya, Sbornik Dokumentov(1917-1926), (1947), Moskova. 
SOYSAL, İsmail (2000), Tarihçeleri ve açıklamaları ile birlikte Türkiye’nin Siyasal Andlaşmaları, cilt 1,TTK, Ankara.

TBMM, Gizli Celse Zabitlart, cilt 1.

TENGIRŞEK, Yusuf Kemal (1981), Vatan Hizmetinde, Kültür Bakanlığı, Ankara. 